\title{
ДОСВІД ПСИХОЛОГО-ПЕДАГОГІЧНОГО СУПРОВОДУ СТУДЕНТІВ ЯК СКЛАДОВА СИСТЕМИ УПРАВЛІННЯ ЯКІСТЮ ПІДГОТОВКИ ЛIКАРІВ
}

\author{
Г. В. Дзяк, Т. О. Перцева, Г. С. Канюка, Г. В. Горбунова
}

Держсавний заклад “Дніпропетровська медична академія Міністерства охорони здоров'я України”

\section{EXPERIENCE OF PSYCHO-PEDAGOGICAL SUPPORT OF STUDENTS AS A PART OF THE QUALITY MANAGEMENT SYSTEM OF DOCTORS' TRAINING}

\author{
H. V. Dzyak, T. O. Pertseva, H. S. Kaniuka, H. V. Horbunova
}

State Institution "Dnipropetrovsk Medical Academy of Ministry of Public Healh of Ukraine”

\begin{abstract}
У статті звернено увагу на значимість психолого-педагогічного супроводу студентів у вирішенні питань підвищення якості підготовки майбутніх лікарів.
\end{abstract}

The article paid attention to the importance of psychological and pedagogical support of students in solving the issues of improving the quality of future doctors.

Вступ. Реформування вищої медичної освіти в Україні спрямовано на вирішення проблеми підвищення якості підготовки студентів до професійної діяльності та удосконалення системи управління якістю освітніми процесами. Сучасні тенденції модернізації та гуманізації освіти ставлять головною метою професійної підготовки формування та розвиток особистості, професійних та особистісних якостей фахівця, оволодіння загальнокультурними і професійними компетенціями, які мають на увазі здібності та готовність до життя, здійснення професійної діяльності в сучасних умовах, оволодіння методологією самоосвіти тощо.

Основна частина. Управління якістю освіти в академії здійснюється в різноманітних напрямках:

- запроваджені у навчальний процес інноваційні розробки новітніх технологій (комплексна навчаюча система з тренажерами "Online Version of Medical Examination Skills Training System" на кафедрі пропедевтики внутрішньої медицини, функціонує навчальний центр “Ендоскопічні технології в медицині” на кафедрі хірургії № 1, введено тренажерний клас на кафедрі хірургічної стоматології, імплантології та пародонтологіï);

- удосконалюється якість матеріально-технічної бази освітнього процесу (щорічно придбаваються комп'ютерна техніка, манекени, муляжі тощо); (ㄷ Г. В. Дзяк, Т. О. Перцева, Г. С. Канюка, Г. В. Горбунова
- посилена система контролю навчального процесу (введено незалежне тестування на кафедрах фундаментальних дисциплін як перший етап підсумкового модульного контролю, проводиться незалежний від кафедр ректорський тестовий контроль на випускаючих кафедрах);

- удосконалюється організація навчального процесу за кредитно-модульною системою (вживають заходів щодо підвищення якості методичного забезпечення, підвищення вимог державних екзаменаційних комісій до випускників, їх компетентності, професійної свідомості і розумінь соціальної відповідальності за результати професійної діяльності тощо);

- вживають заходів щодо підвищення якості викладацького складу та його мотивації щодо ефективності педагогічної та наукової діяльності;

- особлива увага приділяється якісному складу студентів-першокурсників, їх індивідуальним здібностям, особливостям, мотивації до засвоєння знань, практичним навичкам.

У державному закладі “Дніпропетровська медична академія МОЗ України " у 1991 році створена лабораторія психофізіологічних досліджень та були визначені три головних аспекти ії діяльності:

- профорієнтаційна робота з абітурієнтами (на базі академії діяла школа “Юний медик”, iї філії були розта- 
шовані на базі двох центральних районних лікарень та у м. Павлограді і в м. Кривому Розі);

- соціально-психологічний аспект (психологічний супровід студентів під час навчання у вузі);

- третій аспект - психофізіологічне дослідження (відбір студентів у складні медичні спеціальності за психофізіологічними показниками (анестезіологія, реаніматологія, хірургія).

На підставі стандартизованих методик спеціалістами лабораторії були створені відповідні програми. За ці роки у психофізіологічної лабораторії накопичено досвід та створено банк даних обсягом близько десяти тисяч випадків психофізіологічного тестування студентів. Це дає можливість забезпечити психологічний супровід студентів, спільно з деканами вирішувати питання підбору “лідерів” для призначення старост у студентських групах, спільно 3 методичним кабінетом проводити психолого-педагогічні семінари для молодих викладачів тощо.

Прийняття у 2009 році МОН України документів: Положення про психологічну службу системи освіти України (наказ № 616 від 23.07.2009 р.) та наказу № 1248 від 30.12.2009 p. “Про покращення соціально-педагогічного і психологічного супроводу навчально-виховного процесу у вищих навчальних закладах 3-4 рівнів акредитації " підтвердило важливість наявності такої структури у вищому навчальному закладі. Діяльність психологічної служби спрямована на формування професійно компетентної, психологічної та фізично здорової, творчо мислячої, уміючої приймати рішення в екстремальній ситуації особистості, відповідно до вимог сучасного суспільства.

У даний час діяльність лабораторії здійснюється у соціально-психологічному аспекті, який включає три компоненти освіти: навчання, виховання та розвиток. Основні напрямки діяльності лабораторії: діагностично-дослідна робота, психологічне консультування, тренінгово-корекційна робота, психологічна профілактика, психологічне просвітництво.

Діагностично-дослідницька робота - це насамперед психофізіологічне тестування студентів першого курсу та анкетування студентів всіх курсів. Цей напрямок роботи лабораторії дозволив встановити психологічні критерії для прогнозу успішності: для студентів у навчальній діяльності; для лікаря - в майбутній професійній діяльності.

Для студента це: мотивація до навчання; тип нервової системи (працездатність, витривалість, стресостійкість, здатність до навчання; швидкість когнітивних функцій).
Для лікаря - це інтелектуальний рівень особистості, комунікативні здібності, рівень емпатії (співчуття, чуйності, гуманності).

За результатами психофізіологічного тестування визначаються групи “еліти” та “ризику” за наступними показниками: інтелектуальним, емоційним, комунікативним та емпатійним. Зараховані на бюджетну форму навчання відрізняються від прийнятих на контрактне навчання за багатьма параметрами. Встановлено, що на бюджетній формі навчання найбільш висока група інтелектуальної еліти і найменша група ризику щодо навчання. Незважаючи на те, що більшість студентів мають високий рівень комунікативних здібностей, але у кожного третього спостерігається високий нейротизм (роздратованість), у кожного 4-го низький рівень емпатії (вмінь співчувати людям). При контрактній формі навчання результати відрізняються за психологічними показниками: низький відсоток інтелектуальної еліти і дуже високий відсоток групи ризику щодо навчання, студенти мають проблеми в спілкуванні, що так необхідно у професії лікаря. Аналіз психофізіологічних показників студентів у динаміці показує, що в сучасних умовах збільшилась група ризику щодо навчання, зменшилась група еліти, збільшилась група студентів з високим рівнем нейротизму. За останні три навчальних роки виявлені тенденції щодо зниження групи “еліти" з 12,4 \% у 2009-2010 н. р. до 9,5 \% у 20112012 н. р., частка групи "ризику” складає 22,45 \% 21,25 \% відповідно. Група “ризику” за емоційним показником (особистісна тривожність, помисливість, невпевненість у собі, дратівливість) щорічно складає від 20 до $25 \%$.

Група "ризику" за комунікативним показником (низька товариськість) щорічно нараховувала від 7 до $10 \%$ студентів, в останні роки їх кількість зросла до 14,7-15,5 \%. Група “ризику” за емпатійним показником (співчуття, милосердя) щорічно коливається від 18 до 30 \%, у 2011-2012 н. р. вона склала 29\%.

За результатами психофізіологічного тестування психологічне консультування проводиться для всіх студентів першого курсу. Консультування з психологічних проблем проводиться для студентів всіх курсів. 3 них $60 \%$ звертань пов'язані з міжособистісними відносинами, 20 \% - труднощі в адаптації, $10 \%$ емоційні проблеми (страхи, тривоги, невпевненість у собі), 5 \% - вибір спеціальності.

За результатами тестування спеціалістами лабораторії ведеться тренінгово-корекційна робота: тренінги навчання для студентів першого курсу та тренінг спілкування для студентів всіх курсів. За даними ла- 
бораторії можливо виділити кризи студентського віку: криза першого курсу (адаптація); криза четвертого курсу (“крах ілюзій”); криза шостого курсу (страх та неспокій випускника).

Відсутність у студентів результатів психічного та фізичного здоров'я на кожному з цих етапів студентського життя може привести до розвитку неврологічних розладів.

Психологічна профілактика здійснюється двома напрямками: моніторинг “Здоровий спосіб життя” (суб' єктивне уявлення студентів про стан власного здоров’я на 1-му, 3-му, 5-му курсах) та оздоровчий туризм.

Фактори, що впливають на стан здоров'я, на думку студентів: здоровий спосіб життя - 96,6 \% опитаних, організація дозвілля - 94,5 \% опитаних, якість навчального процесу - 95,4 \% опитаних. Причини невідповідності фактору “здоровий спосіб життя”: недостатній сон - 49, 1 \%; нерегулярне харчування - 37,7 \%; недотримання режиму праці та відпочинку - 26,3 \%; відсутність звички активно відпочивати - 24,6 \%; відсутність необхідних позитивних емоцій - 14,1 \%.

Причини невідповідності фактору “Організація свого дозвілля”: немає об’єктивної можливості організувати своє дозвілля так, як хотілося б-51,8 \%; звичка відпочивати пасивно - 19,3 \%; немає відновлення сил при повноцінному відпочинку - 12,3\%; невлаштованість особистого життя - 12,3\%; немає друзів і товаришів за інтересами - 7 \%. Причини невідповідності фактору “Якість навчального процесу”: великий обсяг навчального матеріалу - 51,8 \%; недостатньо часу на самопідготовку - 39,5 \%; втома в ході навчального процесу - 28,9 \%; відсутність необхідної навчальної інформації - 15 \%; нецікаві предмети - $9 \%$, погане ставлення з боку викладачів - 7 \%.

\section{Лiтература}

1. Проблеми інтеграції української медичної освіти у світовий освітній простір : матеріали Всеукраїнської навчально-наукової конференції. - Тернопіль : ТДМУ, 2009. $314 \mathrm{c}$.

2. Впровадження кредитно-модульної системи організації навчального процесу у ВМ(Ф)НЗ України; результати, проблеми та перспективи : матеріали Всеукраїнської
Оздоровчий туризм - новий напрямок роботи, що використовує подорожі як комплекс оздоровчих чинників: психотерапевтичних (спілкування, командна робота); фізіотерапевтичних (чисте повітря, гірська вода, сонячні і морські ванни); лікувально-фізичних (дозована ходьба покращує настрій і роботу всіх систем організму); дієтологічних (здорова їа, відсутність переїдання).

Важливим розділом роботи лабораторії є психологічне просвітництво. Для студентів 1-го курсу в лабораторії підготовлені збірники матеріалів, які дають інформацію щодо самопідготовки: як конспектувати лекції, як працювати з книгою, як краще запам’ ятати інформацію, як підготуватися до сесії і т. д. Фахівцями лабораторії друкуються статті з психологічних проблем в газеті академії “Пульс”, журналі “Медична практика”: “Секрети економії часу”, “Як спілкуватися в колективі з “важкими людьми” та інші. Працюють клуби “Душа” і “Мандри”: а це зустрічі студентів 3 цікавими людьми, виставки творчих робіт викладачів та студентів, перегляд фото і кіноматеріалів про походи студентів, підготовка до міських та обласних фестивалів туристичної пісні тощо.

Висновок. Специфіка діяльності лікаря пред'являє особливі вимоги до рівня психологічної і фізичної підготовки молоді до майбутньої діяльності, ретельного відбору абітурієнтів, які з найбільшою ймовірністю зможуть успішно освоїти професію лікаря. Підвищення якості навчання майбутніх лікарів потребує посилення професійно-орієнтаційної роботи з пошуку свого абітурієнта, психологічного та соціально-педагогічного супроводу протягом всього навчання, підвищення педагогічної майстерності викладацького складу, оптимізації навчального процесу згідно з результатами психофізіологічного тестування студентів.

навчально-наукової конференції. - Тернопіль : ТДМУ, 2010. -493 c.

3. Впровадження нових технологій за кредитно-модульної системи організації навчального процесу у ВМ(Ф)Н3 III-IV рівнів акредитації : матеріали Всеукраїнської навчально-наукової конференції. - Тернопіль : ТДМУ, 2012. - 599 с. 